\title{
Investigation of Relationship Between Chemical Stress Factors and Certain Metabolites Including Cardenolides in Callus Cultures of Endemic Turkish Digitalis L. Species
}

\author{
Gunce SAHIN**1, Sandeep Kumar VERMA², Ekrem GUREL ${ }^{1}$ \\ ${ }^{1}$ Abant Izzet Baysal University, Faculty of Science and Art, Department of Biology, 14280, Bolu, Turkey \\ ${ }^{2}$ Department of Horticulture, Institute of Agriculture \& Life Science, Gyeongsang National University, Jinju \\ 66071, South Korea
}

Received: 28 April 2017 - Accepted: 04 June 2017

\begin{abstract}
The aim of the present research is to obtain relationship between different stress treatments [Cu (copper) and $\mathrm{Hg}$ (mercury)] and content of cardiac glycosides (digoxigenin, gitoxigenin, lanatoside $\mathrm{C}$, digoxin and digitoxin) as secondary metabolites of commercial value for the pharmaceutical industry and to determine the antioxidant metabolites against stress conditions in callus cultures of endemic Turkish Digitalis species. The effects of different stress treatments on cardiotonic glycoside accumulation in D. lamarckii Ivanina, D. trojana Ivanina, D. davisiana Heywood and D. cariensis Boiss. ex Jaub. et Spach were investigated using HPLC. HPLC analysis revealed that all stress conditions were significantly effective at 5\% significance level according to their control groups. The predominant cardiac glycoside was lanatoside C (Lan C) followed by digitoxin, digoxigenin, gitoxigenin and digoxin. No digoxin was detected in all treatments as well as in control groups. For the calibration curves, concentrations of 5, 10, 20, 30 and $40 \mathrm{mg} / 1$ digoxigenin, gitoxigenin, lanatoside $\mathrm{C}$, digoxin and digitoxin were used $\left(R^{2}=0.99\right)$. Cardenolides were eluted with acetonitrile $(A)$ and water $(B)$ gradients as follows: 0 to 20 $\min 20 \%$ (A), $80 \%$ (B); 20 to $23.40 \mathrm{~min} 30 \%$ (A), $70 \%$ (B); 23.40 to $30 \mathrm{~min} 25 \%$ (A), $75 \%$ (B) and 30 to $40 \mathrm{~min}$ $40 \%$ (A), 60\%(B). Average peak area of the glycoside in samples was automatically calculated and monitored by ChemStation LC/MS software against that of standards. Enhanced production of cardenolides was achieved from callus cultures elicited with $50 \mu \mathrm{m} \mathrm{CuSO}_{4}$ and $\mathrm{HgCl}_{2}$. Higher amounts of cardenolides were obtained when callus of four Digitalis species were elicited with CuSO4. Results demonstrated that catalase (CAT, EC 1.11.1.6), superoxide dismutase (SOD, EC 1.15.1.1) activities, the total contents of phenolics and proline were markedly stimulated under stress conditions. All these results indicated that treatments have induced changes in the redox state of callus cells and suggest that this alteration change cardenolides accumulation and antioxidative status in Digitalis L. callus cultures.
\end{abstract}

Keywords: Antioxidant, cardiac glycosides, Digitalis L., heavy metal stress

\section{INTRODUCTION}

Digitalis L. produces various cardiac glycosides which have potential to treat many diseases such as edema, myocardial infarction, arterial hypertension, cardiac dysfunction, angina and hyertropy [1]. Besides their cardiotonic effects, these compounds are also effective chemotherapeutic agents, especially in breast and prostate cancer treatments [2]. Digitalis species is distributed in the Mediterranean region, Western Asia and Europe. Digitalis davisiana Heywood, Digitalis lamarckii Ivanina, Digitalis cariensis Boiss. ex Jaub. et Spach

\footnotetext{
*Corresponding Author E-mail: guncesahin@gmail.com
} 
and Digitalis trojana Ivanina are endemic to Turkey [3]. Traditionally, cell and organ cultures have been used for production of secondary metabolites, but the yield of cardiac glycosides have been low. Attempts have been made to increase concentration of metabolites in shorter period of time. Exogenous addition of biotic and abiotic elicitors is considered to be one of the most promising strategies for the induction of secondary metabolites production [4]. Zhao et al. [5] proposed that these elicitor molecules act as extracellular or intracellular signals and initiate a signal transduction network that is required for the activation of transcription factors, which organize the expression of genes included in plant secondary metabolism [6]. Among the various abiotic elicitors, heavy metal stresses have been considered as effective elicitors for the increased production of secondary metabolites in in vitro cultures. Heavy metal stress has become a headmost environmental threat to crop production. Being a potential hazardous factor, toxic metals decrease the plant growth, yield and sustainability of production, thus can cause the alarming situation for food availability. Plants under the stress environment facing the alterations of cellular protein functions, lipid and thylakoid structures. Disturbance or breakage of these structures is directly linked with plant photosystem that can affect the senescence process $[7,8]$. Copper $(\mathrm{Cu})$, microelement, has important physiological functions in plants. At higher concentrations, it leads to physiological and morphological disturbances, as a consequence decrease the yield [9]. Mercury $(\mathrm{Hg})$ is a toxic metal that can be absorbed from the atmosphere and soil. It can be accumulate in the plant organs and cause to phytotoxic effects. The toxic metal threshold level in the tissue is defined by the 'stress point'. Beyond the stress point, the cell will be irreversibly damaged [10]. These metabolic changes can directly trigger the plant defense system, including enzymatic and non-enzymatic antioxidants to cope with overproduce of reactive oxygen species (ROS) in the cell [11]. As a consequence of unfavorable conditions, activation of genes related to the enzymatic defense system, including catalase (CAT), superoxide dismutase (SOD), guaicol peroxidase (POD), glutathione reductase (GR) and the non-enzymatic antioxidants such as glutathione, ascorbate (vitamin C), carotenoids, $\alpha$ tocopherol (vitamin E), proline and various phenylpropanoid derivatives (phenolic compounds) were observed [12]. On the basis of background information, the aim of this work is to investigate the induction of cardenolide compounds (lanatoside $\mathrm{C}$, digitoxin, digoxigenin, gitoxigenin and digoxin) in $D$. davisiana Heywood, D. lamarckii Ivanina, D. trojana Ivanina and $D$. cariensis Boiss. ex Jaub. et Spach, in response to application of heavy metal toxicity and to determine the correlation between the cardiotonic glycosides accumulation and stress responsive antioxidant defense system.

\section{MATERIAL and METHODS}

\subsection{Plant materials}

Seeds of four endemic Digitalis species (D. davisiana Heywood, D. lamarckii Ivanina, $D$. trojana Ivanina and D. cariensis Boiss. ex Jaub. et Spach) were collected in August to September, 2010. Seeds of D. davisiana and D. cariensis from Alanya-Mahmutlar (N360 31.916', E032014.402') (N360 30.767', E032012.695', 03.09.2010), seeds of D. lamarckii around the Ankara-Kizilcahamam (N40037.709', E032026.265') and D. trojona were collected from the National Park of Ida Mountains (N390 38.885', E0260 57.402').

\subsection{Experimental Design}

The seeds were cultured on MS medium including containing 3\% sucrose and $0.8 \%$ agar ( $\mathrm{pH}$ 5.7-5.8) for germination. Hypocotyl explants were cultured on MS medium including vitamins (0.5 ppm TDZ and 0.25 ppm IAA) (Sahin et al., 2013) for callus induction. After 30 days of culture $50 \mu \mathrm{m} \mathrm{HgCl} 2$ and $50 \mu \mathrm{m} \mathrm{CuSO}_{4}$ were used in cultures in order to expose the callus cultures to chemical stress for 10 days [13]. 


\subsection{Extraction and HPLC analysis of cardenolides}

Cardenolide extraction was determined according to the modified method of Wiegrebe and Witchtl [14]. Qualitative and quantitative analysis of cardenolides were detected and calculated as previously described HPLC protocol [15].

\subsection{Enzyme extraction, protein determination and assays of enzymes}

Callus material was homogenized as previously described protocol [15], then tissue extracts were kept at $-80^{\circ} \mathrm{C}$ for determination of superoxide dismutase (SOD, EC 1.15.1.1) [16] and catalase (CAT, EC 1.11.1.6) activity [17]. The protein content was determined according to Lowry method [18].

\subsection{Total phenolic assay}

The total phenolic content were determined using the Folin-Ciocalteau [19] method. The total phenolic content of extracts was expressed as mg gallic acid equivalents (GAE)/ $\mathrm{g} \mathrm{dw}$.

\subsection{Proline analysis}

Proline was determined according to the method of Bates et al., [20]. Proline content was calculated as $\mu \mathrm{mol}$ proline $/ \mathrm{g} \mathrm{dw}$.

\subsection{Statiscal Analysis}

Data were statistically analyzed using SPSS Version 15.0 (SPSS Inc., Chicago, IL, USA) and Duncan's multiple range test at $P \leq 0.05$. Each treatment was made in triplicate.

\section{RESULTS}

Callus was initiated from hypocotyl explants cultured on MS medium supplemented with $0.25 \mathrm{mg} \mathrm{L}^{-1} \mathrm{IAA}$ and $0.5 \mathrm{mg} \mathrm{L}^{-1} \mathrm{TDZ}$. After 30 days, callus was transferred to MS medium containing $50 \mu \mathrm{m} \mathrm{HgCl}_{2}$ and $50 \mu \mathrm{m} \mathrm{CuSO}_{4}$ for 10 days. Here, we examined the effects of $\mathrm{HgCl}_{2}$ and $\mathrm{CuSO}_{4}$ as an heavy metal stress factors on cultures which induced cardiotonic glycoside accumulation and antioxidant activities in four Digitalis species (D. cariensis, D. davisiana, D. trojana, D. lamarckii). Application of $\mathrm{HgCl}_{2}$ and $\mathrm{CuSO}_{4}$ to the medium were not affected cell viability. However, the colour of the callus changed from green (control group) to brownish with $\mathrm{HgCl}_{2}$ and $\mathrm{CuSO}_{4}$ applications (Figure 1). Results related to cardenolides accumulation of treated and untreated plants of four Digitalis species (D. davisiana Heywood, D. lamarckii Ivanina, D. trojana Ivanina and D. cariensis Boiss. ex Jaub. et Spach) are shown in Table 1.
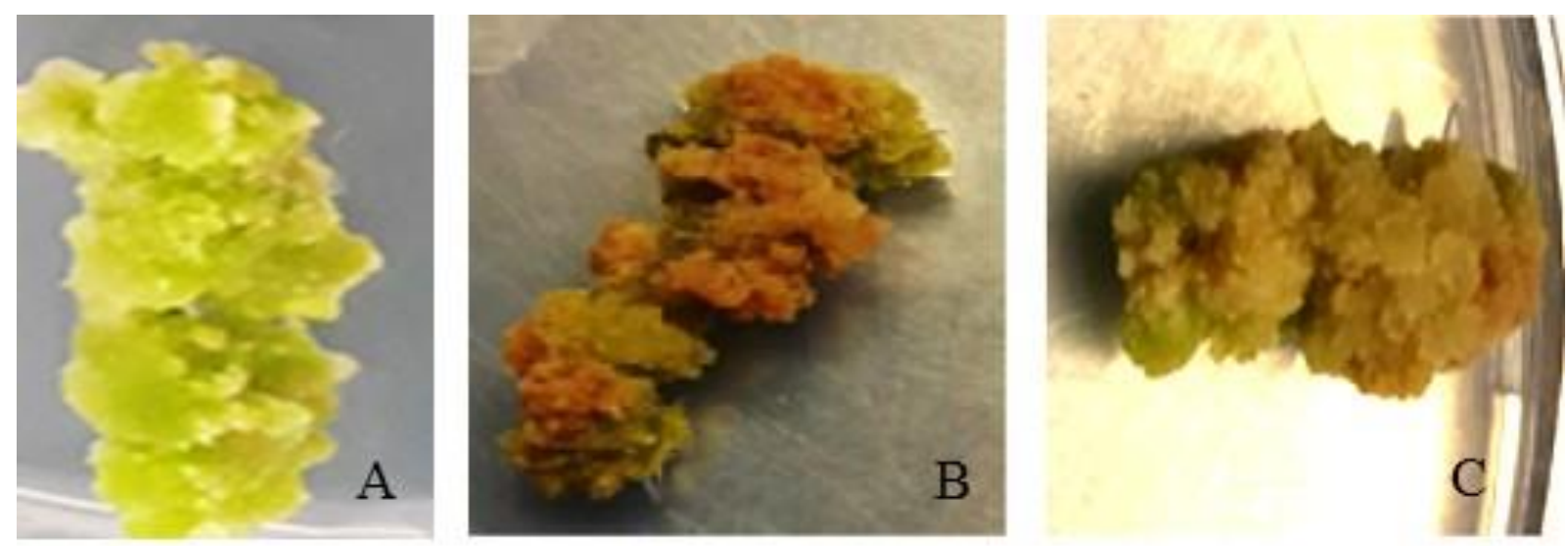

Figure 1. Effects of culture media and stress factors on morphological characters of induced callus: (AC): (A): Callus growth in MS medium $+0.25 \mathrm{mg} \mathrm{L}^{-1} \mathrm{IAA}$ and $0.5 \mathrm{mg} \mathrm{L}^{-1} \mathrm{TDZ}$ (control group), (B): Callus growth in MS+50 $\mu \mathrm{m} \mathrm{HgCl}_{2}$, (C): Callus growth in $\mathrm{MS}+50 \mu \mathrm{m} \mathrm{CuSO}_{4}$ 
Table 1. Results of cardenolides accumulation in the control and elicited callus tissues of Digitalis species. Means followed by different letters in the same column are significantly different $(\mathrm{P}<0.05)$.

\begin{tabular}{|c|c|c|c|c|c|c|}
\hline \multirow[t]{2}{*}{ Species } & \multirow[t]{2}{*}{ Treatments } & \multicolumn{5}{|c|}{ Amount of cardenolides $\left(\mu \mathrm{g} \mathrm{g}^{-1}, \mathrm{dw}\right)$} \\
\hline & & Digoxigenin & Gitoxigenin & Lan $\mathrm{C}$ & Digoxin & Digitoxin \\
\hline \multirow[t]{3}{*}{ D. lamarckii } & Control & $9.04^{\mathrm{h}} \pm 0.62$ & $6.46^{\mathrm{def}_{ \pm} 0.36}$ & $302.04^{\mathrm{i}} \pm 7.49$ & $<\mathrm{LOD}$ & $8.67^{\mathrm{d}} \pm 0.49$ \\
\hline & $\mathrm{CuSO}_{4}$ & $11.41^{\mathrm{ef}} \pm 1.96$ & $6.41^{\mathrm{ef}} \pm 0.51$ & $721.80^{c} \pm 8.78$ & $<\mathrm{LOD}$ & $11.83^{\mathrm{bc}} \pm 3.78$ \\
\hline & $\mathrm{HgCl}_{2}$ & $10.37^{\mathrm{fgh}} \pm 0.41$ & $6.49^{\mathrm{ef}} \pm 0.57$ & $377.23^{\mathrm{g}} \pm 5.20$ & $<\mathrm{LOD}$ & $9.27^{\mathrm{cd}} \pm 2.08$ \\
\hline \multirow[t]{3}{*}{ D. trojana } & Control & $12.96^{\mathrm{de}} \pm 0.56$ & $6.12^{\mathrm{fg}} \pm 0.13$ & $285.63^{j_{ \pm}} \pm 2.57$ & $<\mathrm{LOD}$ & $7.48^{\mathrm{d}} \pm 0.50$ \\
\hline & $\mathrm{CuSO}_{4}$ & $17.13^{\mathrm{b}} \pm 1.31$ & $7.62^{\mathrm{cd}} \pm 1.13$ & $619.83^{\mathrm{e}} \pm 7.23$ & $<\mathrm{LOD}$ & $9.66^{\mathrm{cd}} \pm 0.77$ \\
\hline & $\mathrm{HgCl}_{2}$ & $12.49^{\mathrm{de}} \pm 1.10$ & $6.61^{\mathrm{def}} \pm 0.83$ & $346.37^{\mathrm{h}} \pm 9.47$ & $<\mathrm{LOD}$ & $8.68^{\mathrm{d}} \pm 0.77$ \\
\hline \multirow[t]{3}{*}{ D. davisiana } & Control & $9.56^{\mathrm{gh}} \pm 0.10$ & $5.16^{\mathrm{g}} \pm 0.20$ & $259.85^{\mathrm{k}} \pm 8.17$ & $<\mathrm{LOD}$ & $7.55^{\mathrm{d}} \pm 0.50$ \\
\hline & $\mathrm{CuSO}_{4}$ & $18.99^{\mathrm{a}} \pm 0.17$ & $7.75^{\mathrm{c}} \pm 0.21$ & $844.097^{\mathrm{b}} \pm 7.89$ & $<\mathrm{LOD}$ & $13.52^{\mathrm{b}} \pm 0.93$ \\
\hline & $\mathrm{HgCl}_{2}$ & $15.44^{\mathrm{c}} \pm 0.77$ & $7.34^{\text {cde }} \pm 0.33$ & $461.13^{\mathrm{f}} \pm 6.08$ & $<\mathrm{LOD}$ & $9.33^{\mathrm{cd}} \pm 0.31$ \\
\hline \multirow[t]{3}{*}{ D. cariensis } & Control & $10.73^{\mathrm{fg}} \pm 0.17$ & $8.33^{\mathrm{c}} \pm 0.47$ & $280.71^{\mathrm{j}_{ \pm}} 7.14$ & $<$ LOD & $9.06^{\mathrm{d}} \pm 0.27$ \\
\hline & $\mathrm{CuSO}_{4}$ & $14.09^{\mathrm{cd}} \pm 0.59$ & $12.16^{\mathrm{a}} \pm 0.63$ & $939.21^{\mathrm{a}} \pm 9.09$ & $<\mathrm{LOD}$ & $16.13^{\mathrm{a}} \pm 0.54$ \\
\hline & $\mathrm{HgCl}_{2}$ & $13.07^{\mathrm{d}} \pm 0.43$ & $10.01^{\mathrm{b}} \pm 0.67$ & $673.23^{\mathrm{d}} \pm 6.58$ & $<\mathrm{LOD}$ & $13.92^{\mathrm{ab}} \pm 0.16$ \\
\hline
\end{tabular}

Note: LOD; limit of detection.

Addition of $\mathrm{HgCl}_{2}$ and $\mathrm{CuSO}_{4}(50 \mu \mathrm{m})$ into media significantly affected the cardenolides accumulation as compared to control. Especially, $\mathrm{CuSO}_{4}$ treatments played a pivotal role to the accumulation of cardenolides. Lanatoside $\mathrm{C}$ was the predominant cardiac glycoside followed by digoxigenin, digitoxin, gitoxigenin and digoxin. On the other hand, the content of digoxin was below the limit of detection in all treatments. The use of $\mathrm{CuSO}_{4}$ and $\mathrm{HgCl}_{2}$ led to a drastic increase in the accumulation of Lan $\mathrm{C}$ in all Digitalis species. The control (non-treated) callus produced $302.04 \pm 7.49 \mu \mathrm{g} / \mathrm{g}$ dw Lan $\mathrm{C}$ while those treated with chemical stress by $\mathrm{CuSO}_{4}$ and $\mathrm{HgCl}_{2}$ producing $721.80 \pm 8.78 \mu \mathrm{g} / \mathrm{g} \mathrm{dw}$ and $377.23 \pm 5.20 \mu \mathrm{g} / \mathrm{g}$ dw Lan C respectively in $D$. lamarckii callus cultures. Similar to D. lamarckii, the positive correlation between the accumulation of Lan $\mathrm{C}$ and $\mathrm{CuSO}_{4}-\mathrm{HgCl}_{2}$ applications was detected in D. trojana callus cultures. $285.63 \pm 2.57 \mu \mathrm{g} / \mathrm{g}$ dw Lan $\mathrm{C}$ was found in the control (non-treated) callus while those treated with chemical stress by $\mathrm{CuSO}_{4}$ and $\mathrm{HgCl}_{2}$ producing $619.83 \pm 7.23 \mu \mathrm{g} / \mathrm{g} \mathrm{dw}$ and $346.37 \pm 9.47 \mu \mathrm{g} / \mathrm{g} \mathrm{dw}$ Lan C, respectively. In D. davisiana cultures, the accumulation of Lan C was significantly induced as a concequence of $\mathrm{CuSO}_{4}$ and $\mathrm{HgCl}_{2}$. Lan $\mathrm{C}$ of control was $259.85 \pm 8.17 \mu \mathrm{g} / \mathrm{g} \mathrm{dw}$ while those treated with chemical stress by $\mathrm{CuSO}_{4}$ and $\mathrm{HgCl}_{2}$ producing $844.097 \pm 7.89 \mu \mathrm{g} / \mathrm{g} \mathrm{dw}$ and $461.13 \pm 6.08 \mu \mathrm{g} / \mathrm{g} \mathrm{dw}$ Lan C, respectively. CuSO4 as well as $\mathrm{HgCl}_{2}$ stress was followed by a significantly enhanced accumulation of Lan $\mathrm{C}$ in D. cariensis callus cultures. The control (non-treated) callus produced $280.71 \pm 7.14 \mu \mathrm{g} / \mathrm{g}$ dw Lan C while those cultured on under chemical stress by $\mathrm{CuSO}_{4}$ and $\mathrm{HgCl}_{2}$ producing $939.21 \pm 9.09 \mu \mathrm{g} / \mathrm{g} \mathrm{dw}$ and $673.23 \pm 6.58 \mu \mathrm{g} / \mathrm{g} \mathrm{dw}$ Lan $\mathrm{C}$ respectively. Although a noticeable increase was observed in digitoxin, digoxigenin content under the exposure of $\mathrm{CuSO}_{4}$, there was not any significant increase in gitoxigenin, digitoxin, digoxigenin content under the exposure of $\mathrm{HgCl}_{2}$ compared to non-treated callus in D. lamarckii. In D. trojana cultures, digoxigenin $(17.13 \pm 1.31 \mu \mathrm{g} / \mathrm{g} \mathrm{dw})$ and gitoxigenin levels $(7.62 \pm 1.13 \mu \mathrm{g} / \mathrm{g} \mathrm{dw})$ were significantly increased under $\mathrm{CuSO}_{4}$ stress. But it is apparent that, at 5\% significance level, there was not any significant change observed between control groups and digitoxin content under both applied treatments. Addition of $\mathrm{CuSO}_{4}$ and $\mathrm{HgCl}_{2}$ into the medium significantly increased the digoxigenin, gitoxigenin and digitoxin content in $D$. davisiana and $D$. cariensis callus cultures as compared with respective controls. The data regarding the antioxidant and non-enzymatic antioxidant enzymes are presented in 
Table 2. Activities of antioxidant enzymes such as superoxide dismutase (SOD), catalase (CAT) were significantly enhanced in all species under $50 \mu \mathrm{m} \mathrm{CuSO} 4$ and $\mathrm{HgCl}_{2}$ treatments as compared with respective controls.

Table 2. Effect of different treatments of heavy metals on enzymatic and non-enzymatic antioxidant activities in the callus cultures of Digitalis species.

\begin{tabular}{|c|c|c|c|c|c|}
\hline Species & Treatments & SOD & CAT & Total phenolic & Proline \\
\hline \multirow[t]{3}{*}{ D. lamarckii } & Control & $0.14^{\mathrm{g}} \pm 0.04$ & $19.30^{\mathrm{d}} \pm 0.70$ & $154.45^{\mathrm{k}} \pm 0.72$ & $0.76^{\mathrm{j}} \pm 0.006$ \\
\hline & $\mathrm{CuSO}_{4}$ & $0.55^{\mathrm{de}^{2}} \pm 0.07$ & $28.61^{\mathrm{a}} \pm 1.20$ & $196.12^{\mathrm{i}} \pm 1.25$ & $1.33^{\mathrm{e}} \pm 0.006$ \\
\hline & $\mathrm{HgCl}_{2}$ & $0.31^{\mathrm{f}} \pm 0.03$ & $21.60^{c} \pm 0.94$ & $174.87^{\mathrm{j}} \pm 0.72$ & $1.23^{\mathrm{g}} \pm 0.012$ \\
\hline \multirow[t]{3}{*}{ D. trojana } & Control & $0.16^{\mathrm{g}} \pm 0.05$ & $15.55^{\mathrm{f}} \pm 0.98$ & $219.46^{\mathrm{g}} \pm 0.72$ & $0.72^{\mathrm{k}} \pm 0.010$ \\
\hline & $\mathrm{CuSO}_{4}$ & $0.46^{\mathrm{e}} \pm 0.08$ & $23.50^{\mathrm{b}} \pm 1.31$ & $276.54^{\mathrm{d}} \pm 1.90$ & $1.29^{f} \pm 0.006$ \\
\hline & $\mathrm{HgCl}_{2}$ & $0.36^{\mathrm{f}} \pm 0.09$ & $21.85^{\mathrm{c}} \pm 1.41$ & $238.20^{\mathrm{f}} \pm 1.44$ & $1.13^{\mathrm{h}} \pm 0.006$ \\
\hline \multirow[t]{3}{*}{ D. davisiana } & Control & $0.48^{\mathrm{e}} \pm 0.05$ & $11.45^{\mathrm{gh}} \pm 0.59$ & $198.62^{h} \pm 1.76$ & $0.76^{\mathrm{j}} \pm 0.006$ \\
\hline & $\mathrm{CuSO}_{4}$ & $0.88^{\mathrm{b}} \pm 0.04$ & $17.68^{\mathrm{e}} \pm 1.05$ & $371.95^{\mathrm{b}} \pm 0.88$ & $1.68^{\mathrm{b}} \pm 0.012$ \\
\hline & $\mathrm{HgCl}_{2}$ & $0.78^{\mathrm{c}} \pm 0.02$ & $14.82^{\mathrm{f}} \pm 0.44$ & $277.37^{\mathrm{d}} \pm 1.76$ & $1.46^{\mathrm{d}} \pm 0.010$ \\
\hline \multirow[t]{3}{*}{ D. cariensis } & Control & $0.46^{\mathrm{e}} \pm 0.03$ & $8.24^{\mathrm{i}} \pm 0.93$ & $252.38^{\mathrm{e}} \pm 1.25$ & $0.81^{\mathrm{i}} \pm 0.006$ \\
\hline & $\mathrm{CuSO}_{4}$ & $1.14^{\mathrm{a}} \pm 0.01$ & $12.66^{\mathrm{g}} \pm 0.63$ & $476.95^{\mathrm{a}} \pm 0.72$ & $1.82^{\mathrm{a}} \pm 0.006$ \\
\hline & $\mathrm{HgCl}_{2}$ & $0.64^{\mathrm{d}} \pm 0.05$ & $10.69^{\mathrm{hi}} \pm 0.63$ & $330.29^{c} \pm 1.90$ & $1.66^{\mathrm{c}} \pm 0.010$ \\
\hline
\end{tabular}

Note: Values followed by same small letters are not significantly different at $\mathrm{P}<0.05$.

The CAT activity in control group ranged from $8.24 \mu \mathrm{mol}_{2} \mathrm{O}_{2} / \mathrm{min} / \mathrm{mg}$ protein for $D$. cariensis to $19.30 \mu \mathrm{mol} \mathrm{H}_{2} \mathrm{O}_{2} / \mathrm{min} / \mathrm{mg}$ protein for $D$. lamarckii followed by $15.55 \mu \mathrm{mol}$ $\mathrm{H}_{2} \mathrm{O}_{2} / \mathrm{min} / \mathrm{mg}$ protein for $D$. trojana. When incubating callus with $50 \mu \mathrm{m} \mathrm{CuSO} 4$ induced CAT activity ranged from $12.66 \mu \mathrm{mol} \mathrm{H}_{2} \mathrm{O}_{2} / \mathrm{min} / \mathrm{mg}$ protein for $D$. cariensis to $28.61 \mu \mathrm{mol}$ $\mathrm{H}_{2} \mathrm{O}_{2} / \mathrm{min} / \mathrm{mg}$ protein for $D$. lamarckii followed by $23.50 \mu \mathrm{mol} \mathrm{H}_{2} \mathrm{O}_{2} / \mathrm{min} / \mathrm{mg}$ protein for D. trojana. Addition of $50 \mu \mathrm{m} \mathrm{HgCl}_{2}$ to the media also enhanced CAT activity ranged from 10.69 $\mu \mathrm{mol} \mathrm{H}_{2} \mathrm{O}_{2} / \mathrm{min} / \mathrm{mg}$ protein for $D$. cariensis to $28.61 \mu \mathrm{mol} \mathrm{H}_{2} \mathrm{O}_{2} / \mathrm{min} / \mathrm{mg}$ protein for $D$. lamarckii. Exposure of heavy metals was followed by a remarkable increase in SOD activity as compared to the control groups. In control, SOD activity ranged from $0.14 \mathrm{U} / \mathrm{mg}$ protein for $D$. lamarckii to $0.48 \mathrm{U} / \mathrm{mg}$ protein for $D$. davisiana followed by $0.46 \mathrm{U} / \mathrm{mg}$ protein for $D$. cariensis. While that cultured expose with $\mathrm{CuSO}_{4}$ induced SOD activity ranged from $0.55 \mathrm{U} / \mathrm{mg}$ protein for D.lamarckii to $1.14 \mathrm{U} / \mathrm{mg}$ protein for D. cariensis. Exogenously applied $\mathrm{HgCl}_{2}$ induced SOD activity ranged from $0.31 \mathrm{U} / \mathrm{mg}$ protein for D.lamarckii to $0.78 \mathrm{U} / \mathrm{mg}$ protein for $D$. davisiana. Besides the enzymatic defense machinery, we also studied non-enzymatic antioxidant response under different treatments of heavy metals. Non-enzymatic antioxidant named as total phenolic and proline levels were increased in all species under $\mathrm{CuSO}_{4}$ and $\mathrm{HgCl}_{2}$ stress as compared to control. Maximum total phenolic and proline production were determined as $476.95 \mu \mathrm{g} \mathrm{GA} \mathrm{mg}^{-1}$ (1.88 -fold higher than control) and $1.82 \mu \mathrm{mol} \mathrm{g}^{-1}$ (2.24- fold higher than control) with the elicitation of $\mathrm{CuSO}_{4}$ respectively.

\section{DISCUSSION}

Plant secondary metabolism is the source for many fine chemicals of commercial importance. One group of natural products of major interest in the pharmaceutical industry is cardiac glycosides from Digitalis species. Levels of plant carbon-based secondary compounds are partly under genetic control and determined in part by environmental conditions [21] therefore, in order to maximise the production of a specific natural product, it will be necessary to understand the various factors that control and influence its biosynthesis. In the case of 
Digitalis plants, previous studies have reported that cardenolide biosynthesis is basically dependent on morphological differentiation [22] and genotype [23], although numerous environmental factors may determine, in a greater or lesser degree, plant productivity. Thus, it is known the influence that mineral nutrients [24, 25], $\mathrm{CO}_{2}$ and water stress [26], and light conditions [27] exert on cardenolide accumulation. Moreover, in our previous papers, we showed that $\mathrm{H}_{2} \mathrm{O}_{2}$ pre-treatment [15] and elimination of $\mathrm{Ca}, \mathrm{Mg}$ or both from the medium [28] resulted in an increase in cardenolides, enzymatic and non-enzymatic antioxidants in callus cultures of Digitalis davisiana Heywood, Digitalis lamarckii Ivanina, Digitalis trojana Ivanina and Digitalis cariensis Boiss. ex Jaub. et Spach. Elicitation strategies have been widely used to induce the production of secondary metabolites in in vitro cell cultures [29]. In the light of earlier studies, it was concluded that $\mathrm{H}_{2} \mathrm{O}_{2}$ increase occurred after $\mathrm{Cu}, \mathrm{Cd}$ [30] and $\mathrm{Hg}$ [13] treatment of A. thaliana and S. lycopersicum, respectively. Similarly, Smith et al. [31] showed that production of umbelliferone, which is a phytoalexin produced in response to stress or infection in whole plants, was stimulated in suspension cultures of Ipomoea batatas (L.) Poir. using $\mathrm{HgCl}_{2}$. Korsangruang et al. [32] found that $\mathrm{CuSO}_{4}$ enhanced the accumulation of isoflavonoid compounds in Pueraria candollei cell suspension culture. However, there are not any reports of Digitalis tissue cultures in which improvements in cardenolide production have been achieved by heavy metal treatments.

The more recent identification and characterization of several enzymes/genes involved in pregnane and cardenolide metabolism, such as $3 \beta$-hydroxysteroid dehydrogenase and progesterone $5 \beta$-reductase. P $5 \beta \mathrm{R}$ is considered to be a key enzyme in cardenolide biosynthesis as: it is the first stereospecific enzyme of the pathway leading to $5 \beta$-configured derivatives; it appears to be the initial step in cardenolide biosynthesis. Pérez-Bermúdez et al. [33] indicated that P5 $\beta \mathrm{R} 2$ is a critical component for the chemical defense of foxglove plants against herbivores, through cardenolide accumulation, in association with ethylene and $\mathrm{H}_{2} \mathrm{O}_{2}$ signaling in Digitalis purpurea. Available information suggests that $\mathrm{H}_{2} \mathrm{O}_{2}$ directly regulates the expression of numerous genes involved in plant defense and the related pathways such as antioxidant enzymes, defense proteins and transcription factors [34]. In our studies, heavy metal stress significantly induced cardenolide production in callus cultures of all Digitalis species. The increase in secondary metabolite concentrations in the callus cultures under heavy metal stress may also be associated with the alterations in the activity of P5 $\beta R 2$ gene related to cardenolides. This was probably due to the reason that heavy metal-induced ROS generation was responsible for transcriptional activation of genes encoding enzymes involved in cardenolide biosynthesis. Although, the applications of heavy metals significantly increased the cardenolides accumulation in all Digitalis species, there was no digoxin detected in all treatments. It is well known that digilanidase enzyme catalyzed deglucosylation and subsequent deacetylation of Lan $\mathrm{C}$ to make into digoxin in the leaves [35]. This was probably due to the reason that the amount of digoxin in the callus tissues examined was found to be below the detection limit of the determination used.

In current work, CAT and SOD activity were significantly increased with the $\mathrm{CuSO}_{4}$ and $\mathrm{HgCl}_{2}$. According to Romero-Puertas et al. [36], many heavy metals could result in increased activity of NADPH oxidase partially related with $\mathrm{O}_{2}^{-}$formation. Correspondingly, heavy metalinduced $\mathrm{O}_{2}^{-}$formation could cause to transcriptional activation of genes responsible for antioxidative enzymes. $\mathrm{O}_{2}^{-}$formation could be associated with an increased activity of SOD for conversion and parallel increased activity of CAT. Furthermore, Mittler [37] reported that increased level of antioxidants has a pivotal role in deteriorating the ROS activity, thus plants could be able to maintain their physiological functions under the stress environment. Along with primary defense mechanism, plants also activated their non-enzymatic antioxidant system named as phenolics and proline as a result of biotic and abiotic stresses, including heavy metal 
toxicity [38]. Stress induced proline accumulation can reduce photochemical activity losses and the production of free radicals in the thylakoid membrane of the chloroplast [39]. Thus, proline contributed to arrest photo inhibitory damage in plants. Many plants accumulate proline at higher concentration in response to toxic concentrations of heavy metals [40]. Some researchers conclude that proline accumulation is not related to protection against metal stress [41], is just a symptom of injury. On the contrary, it has been suggested that proline might have an adaptive role related to survival of plants against heavy metal toxicity [42]. Zengin and Munzuroglu [43] showed that copper and mercury toxicity increased the proline content of the leaves of bean (Phaseolus vulgaris L.) seedlings. A similar observation was also recorded in our experiment that there were a positive correlation between metal toxicity and proline accumulation in callus cultures of Digitalis species. Therefore, we may conclude that proline may have a protective an adaptive role against stress conditions.

Studies suggested that $\mathrm{H}_{2} \mathrm{O}_{2}$ contents increased under both biotic and abiotic stresses induced expression of phenyl ammonia lyase (PAL) accompanied with the de novo synthesis of phenolics [44]. Phenolic compounds have antioxidant action because they are particularly bind iron and copper owing to their high tendency to chelate metals [45]. The content of free phenols was found to increase in two lines of wheat (T. aestivum) and root cultures of Lupinus albus L. with increasing $\mathrm{Cu}$ and $\mathrm{Hg}$ concentration in the medium, respectively. [46, 47]. In our studies, the increase in phenolic levels observed in the callus cultures of Digitalis species to reduce the oxidative stress caused by $\mathrm{Cu}$ and $\mathrm{Hg}$.

\section{CONCLUSION}

This study demonstrated the role of heavy metals in the stimulated production of cardenolides in the callus cultures of Digitalis species. The productivity of cardenolides was found to be dependent on types of species and two elicitors. The present study has established that $\mathrm{CuSO}_{4}$ is a better elicitor than $\mathrm{HgCl}_{2}$ for cardenolide production from Digitalis callus cultures. This study would help to intentionally manipulate elicitation strategy to improve the yield of cardenolides profile in the callus cultures as well as to extend this protocol for large scale production of cardenolides in bioreactor utilizing Digitalis species in order to cope up with the demand for cardenolides in international pharmaceutical markets in future. Our results also showed that enzymatic and non-enzymatic antioxidative system are sensitive to these stress factors. Different accumulation trends were detected between individual compounds against applied treatments. We expect that further analysis of cardenolides and antioxidant molecules will provide insights into the regulatory relationships among these molecules and the role of these molecules in the establishment of mechanism for cardenolide production. The results presented in this work regarding the analysis of cardenolides under stress conditions are believed to create a useful base for the future studies in understanding the antioxidant mechanism which can be employed for the improvement of a large scale production of cardenolides.

\section{Acknowledgement}

This study was supported by the Abant Izzet Baysal University Research Foundation (Project No: 2010.03.01.341).

\section{Conflict of Interests}

Authors declare that there is no conflict of interests.

\section{REFERENCES}

[1]. Baytop, T. (1999). Türkiye'de Bitkilerle Tedavi. Istanbul: Nobel Tıp Kitabevi. 
[2]. Newman, R.A., Yang P., Pawlus A.D., \& Block K.I. (2008). Cardiac glycosides as novel cancer therapeutic agents. Molecular Interventions, 8, 36-49.

[3]. Verma, S.K., Sahin, G., Yucesan, B., Sahbaz, N., Eker, I., Gurel, S., \& Gurel, E. (2012). Direct somatic embryogenesis from hypocotyl segments of Digitalis trojana Ivan and subsequent plant regeneration. Industrial Crops and Products, 40, 76-80.

[4]. Radman, R., Saez, T., Bucke, C., \& Keshavarz, T. (2003). Elicitation of plants and microbial cell systems. Biotechnology and Applied Biochemistry, 37, 91-102.

[5]. Zhao, J., Davis, L.C., \& Verpoorte, R. (2005). Elicitor signal transduction leading to production of plant secondary metabolites. Biotechnology Advances, 23, 283-333.

[6]. Kim, O.T., Bang, K.H., Kim, Y.C., Hyun, D.Y., Kim, M.Y., \& Cha, S.W. (2009). Upregulation of ginsenoside and gene expression related to triterpene biosynthesis in ginseng hairy root cultures elicited by methyl jasmonate. Plant Cell Tissue and Organ Culture, 98, 25-33.

[7]. Lin, C.C., Chen, L.M., Liu, Z.H. (2005). Rapid effect of copper on lignin biosynthesis in soybean roots. Plant Science, 168, 855-861.

[8]. Maksymiec, W. (2007). Signalling responses in plants to heavy metal stress. Acta Physiologiae Plantarum, 29, 177-187.

[9]. Agrawal, V., \& Sharma, K. (2006). Phytotoxic effects of $\mathrm{Cu}, \mathrm{Zn}, \mathrm{Cd}$ and $\mathrm{Pb}$ on in vitro regeneration and concomitant protein changes in Holarrhena antidysenterica. Biologia Plantarum, 50, 307-310.

[10]. Parmar, G.N., \& Chanda, V.S. (2005). Effects of Mercury and Chromium on Peroxidase and IAA Oxidase Enzymes in the Seedlings of Phaseolus vulgaris. Turkish Journal of Biology, 29, 15-21.

[11]. Shanker, A.K., Cervantes, C., Loza-Tavera, H., \& Avudainayagam, S. (2005). Chromium toxicity in plants. Environment International, 31, 739-753.

[12]. Swaran, J.S.F. (2009). Structural, chemical and biological aspects of antioxidants for strategies against metal and metalloid exposure. Oxidative Medicine and Cellular Longevity, 2, 191-206.

[13]. Cho, U., \& Park, J. (2000). Mercury induced oxidative stress in tomato seedlings. Plant Science, 156, 1-9.

[14]. Wiegrebe, H., \& Wichtl, M. (1993) High-performance liquid chromatographic determination of cardenolides in Digitalis leaves after solid-phase extraction. Journal of Chromatography A, 630, 402-407.

[15]. Cingoz, S.G., Verma, S.K., \& Gürel, E. (2014). Hydrogen peroxide-induced antioxidant activities and cardiotonic glycoside accumulation in callus cultures of endemic Digitalis species. Plant Physiology and Biochemistry, 82, 89-94.

[16]. Sun, Y., Oberley, L.W., \& Li, Y. (1988). A simple method for clinical assay of superoxide dismutase. Clinical Chemistry, 34, 497-500.

[17]. Lartillot, S., Kedziora, P., \& Athias, A. (1988). Purification and characterization of a new fungal catalase. Preparative Biochemistry and Biotechnology, 18, 241-246.

[18]. Lowry, O.H., Rosebrough, N.J., Farr, A.L., \& Randall, R.J. (1951). Protein measurement with the Folin Phenol Reagent. The Journal of Biological Chemistry, 193, 265-75.

[19]. Marigo, G. (1973). Sur une méthode de'fractionnement et d' estimation des composés phénoliques chez les vegétaux. Analusis, 2, 106-110.

[20]. Bates, L.S., Waldren, R.P., \& Teare, I.D. (1973). Rapid determination of free proline for water-stress studies. Plant Soil, 39, 205-207. 
[21]. Koricheva, J., Larssson, S., Haukioja, E., \& Keinanen, M. (1998). Regulation of woody plant secondary metabolism by resource availability: hypothesis testing by means of meta-analysis. Okios, 83, 121-226.

[22]. Eisenbeiß, M., Kreis, W., \& Reinhard E. (1999). Cardenolide biosynthesis in light- and dark-grown Digitalis lanata shoot cultures. Plant Physiology and Biochemistry, 37,1323.

[23]. Gavidia, I., Del Castillo Agudo, L., \& Perez-Bermudez, P. (1996). Selection and longterm cultures of high-yielding Digitalis obscura plants: RAPD markers for analysis of genetic stability. Plant Science, 121, 197-205.

[24]. Gavidia, I., \& Perez-Bermudez, P. (1997). Digitalis obscura cardenolides effect of macronutrient concentration and $\mathrm{N}$ source on growth and productivity of shoot-tip cultures. Phytochemistry, 46, 273-238.

[25]. Roca-Perez, L., Boluda, R., \& Perez-Bermudez, P. (2004). Soil-plant relationships, micronutrient contents and cardenolide production L. in natural populations of Digitalis obscura. Journal of Plant Nutrition and Soil Science, 167, 79-84.

[26]. Stuhlfauth, T., Klug, K., \& Fock, H.P. (1987). The production of secondary metabolites by Digitalis lanata during $\mathrm{CO}_{2}$ enrichment and water stress. Phytochemistry, 26, 27352739.

[27]. Brugidou, C., Jacques, M., Cosson, L., Jarreau, F.X., \& Ogerau, T. (1988). Growth and digoxin content in Digitalis lanata in controlled conditions and natural environment. Planta Medica, 54, 262-265.

[28]. Sahin, G., Verma, S.K., \& Gürel, E. (2013). Calcium and magnesium elimination enhances accumulation of cardenolides in callus cultures of endemic Digitalis species of Turkey. Plant Physiology and Biochemistry, 73, 139-143.

[29]. Palacio, L., Baeza, C., Cantero, J.J., Cusido', R., \& Goleniowsi, M.E. (2008). In Vitro propagation of "Jarilla" (Larrea divaricata CAV.) and secondary metabolite production. Biological and Pharmaceutical Bulletin, 31, 2321-2325.

[30]. Maksymiec, W., \& Krupa, Z. (2006). The effects of short term exposition to Cd, excess $\mathrm{Cu}$ ions and jasmonate on oxidative stress appearing in Arabidopsis thaliana. Environmental and Experimental Botany, 57, 187-194.

[31]. Smith, R.A., Drummond, S., Haines, A., Porter, J.R., \& Hock, R.S (2001). Induction of umbelliferone in sweet potato cell suspension culture using mercuric chloride. Biotechnological Letters, 23, 1397-1400.

[32]. Korsangruang, S., Soonthornchareonnon, N., Chintapakorn, Y., Saralamp, P., \& Prathanturarug, S. (2010). Effects of abiotic and biotic elicitors on growth and isoflavonoid accumulation in Pueraria candollei var. candollei and P. Candollei var. mirifica cell suspension cultures. Plant Cell Tissue and Organ Culture, 103, 333-342.

[33]. Perez-Bermudez, P., Garcia, A.A.M., Tunon, I., \& Gavidia, I. (2010). Digitalis purpurea P5 $\beta R 2$, encoding steroid $5 \beta$-reductase, is a novel defense-related gene involved in cardenolide biosynthesis. New Phytologist, 185, 687-700.

[34]. Hung, S.H., Yu, C.W., Lin, C.H. (2005). Hydrogen peroxide functions as a stress signal in plants. Botanical Bulletin Academia Sinica, 46, 1-10.

[35]. Ikeda, Y., Fujii, Y., \& Yamazaki, M. (1992). Determination of Lanatoside C and Digoxin in Digitalis lanata by HPLC and its Application to Analysis of the Fermented Leaf Powder. Journal of Natural Products, 55, 748-752.

[36]. Romero-Puertas, M.C., Perazzolli, M., Zago, E.D., \& Delledonne, M. (2004). Nitric oxide signalling functions in plant-pathogen interactions. Cellular Microbiology, 6, 795-803. 
[37]. Mittler R. (2002). Oxidative stress, antioxidants and stress tolerance. Trends in Plant Science, 7, 405-410.

[38]. Chen, C.T., Chen, L.M., Lin, C.C., \& Kao, C.H. (2001). Regulation of Proline Accumulation in Detached Rice Leaves Exposed to Excess Copper. Plant Science, 160, 283-290.

[39]. Alia, A., Saradhi, P.P., \& Mohanty P. (1991). Proline enhances primary photochemical activities in isolated thylakoid membranes of Brassica juncea by arresting photo inhibitory damage. Biochemical and Biophysical Research Communications, 181, 12381244.

[40]. Schat, H., Sharma, S.S., \& Vooijs, R. (1997). Heavy metal-induced accumulation of free proline in metal-tolerant and a nontolerant ecotype of Silene vulgaris. Physiologia Plantarum, 101, 477-482.

[41]. Lutts, S., Kinet, J.M., \& Bouharmont, J. (1996). Effects of various salts and of mannitol on ion and proline accumulation in relation to osmotic adjustment in rice (Oryza sativa L.) callus cultures. Journal of Plant Physiology, 149, 186-195.

[42]. Siripornadulsil, S., Train, S., Verma, D.P.S., \& Sayre, R.T. (2002). Molecular mechanisms of proline-mediated tolerance to toxic heavy metals in transgenic microalgae. Plant Cell, $14,2837-2847$.

[43]. Zengin, F.K., \& Munzuroğlu, Ö. (2005). Effects of some heavy metals on content of chlorophyll, proline and some antioxidant chemicals in bean (Phaseolus vulgaris L.) seedlings. Acta Biologica Cracoviensia Series Botanica, 47, 157-164.

[44]. Grant, J.J., Yun, B.W., \& Loake, G.J. (2000). Oxidative burst and cognate redox signaling reported by luciferase imaging: identification of a signal network that functions independently of ethylene, SA and Me-JA but is dependent on MAPKK activity. The Plant Journal, 24, 569-582.

[45]. Jung, C.H., Maeder, V., Funk, F., Frey, B., Sticher, H., \& Frosserd, E. (2003). Release of phenols from Lupinus albus $\mathrm{L}$. roots exposed to $\mathrm{Cu}$ and their possible role in $\mathrm{Cu}$ detoxification. Plant Soil, 252, 301-312.

[46]. Ganeva, G., \& Zozikova, E. (2007). Effect of increasing Cu2+ concentrations on growth and content of free phenols in two lines of wheat (Triticum aestivum) with different tolerance. General and Applied Plant Physiology, 33, 75-82.

[47]. Esteban, E., Morenoa, E., Penalosa, J., Cabrero, J.I., Millan, R., \& Zornoza, P. (2008). Short and long-term uptake of $\mathrm{Hg}$ in white lupin plants: Kinetics and stress indicators. Environmental and Experimental Botany, 62, 316-322. 